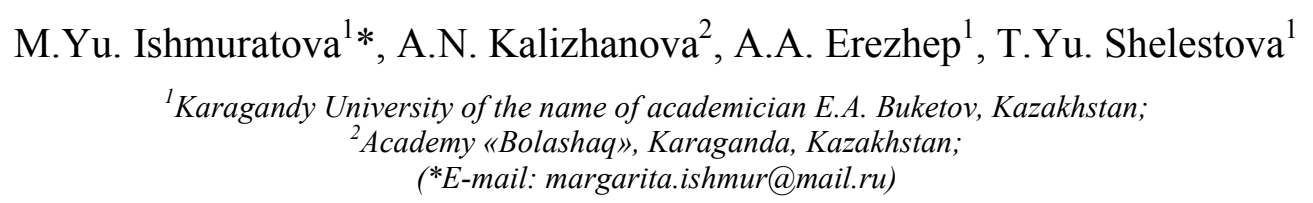

\title{
Effectiveness of the application of a specialized dictionary in the teaching of Biology in English
}

\begin{abstract}
In Kazakhstan, in the process of transition the education to updated content, there is a problem of providing biology classes with the necessary materials in English. At the school and university level, there is a lack of textbooks, manuals and trilingual dictionaries on Biology. This aspect does not allow to learn successfully biology in English, to understand translation of terms, to translate in English. In present article materials on studying of application's efficiency of the using trilingual dictionary (English-Russian-Kazakh, RussianKazakh-English and Kazakh-English-Russian) in senior high school are stated. The effectiveness of the trilingual dictionary on zoology in additional Biology classes in English was evaluated. The results of the studies show that the application of the trilingual dictionary in Biology lessons reliably increases the level of understanding of specialized texts and translation of scientific materials. The use of the dictionary on zoology increases the efficiency of translation from English to Russian and from Russian to English, reduces the time required for translation.
\end{abstract}

Keywords: trilingual dictionary, school, experiment on translation, biology training in English, specialized biological terms, accuracy of the translation.

\section{Introduction}

One of the most important aspects of economic and social modernization of education system, taking place in Kazakh society, is language policy $[1,2]$. Within the framework of this program it is assumed that school disciplines of the natural science cycle, such as Physics, Biology, Chemistry and Information and Communication Technologies (here in after ICT) should be taught in high school in English $[2,3]$.

An analysis of the material provision of schools indicates that there is a shortage of additional materials to ensure English-language classes. One of problems is the lack of specialized dictionaries and glossaries on Biology, Physics, Chemistry and ICT [4-6].

Teaching English at school is aimed at achieving general communication skills and competencies, however, does not cover the needs of specialized areas of natural science subjects. In addition, many terms (compound, connection, bond, equilibrium and others) in physics, chemistry or biology have different definitions [5].

Working with scientific and scientific-cognitive texts in English may not lead to a complete understanding of the text, as not all terms can be adequately understood by school-students and school teachers. Difficulties in working with English-language textbooks can lead to a decrease in the level of understanding, as well as a lack of understanding of terms in the native language (Russian or Kazakh).

There is a problem as the need to ensure simultaneous understanding of terms in 3 languages (Kazakh, Russian and English) in order to be able to freely navigate in text, video or audio information [7, 8].

Today, Kazakhstan is creating bilingual and trilingual dictionaries on separate disciplines of higher education [9]. Thus, there are trilingual glossaries and terminology dictionaries on Common Physics, Higher Mathematics, Organic Chemistry, Botany, Ecology and the Base of Invertebrate Zoology. However, these dictionaries are not easily accessible to a wide audience; also they are not suitable for school disciplines $[5,10]$.

Thus, we face the problem of creating and testing a trilingual dictionary on the school course of Biology.

Proceeding from the aforesaid, the purpose of this article is to carry out approbation of the trilingual dictionary on Zoology on additional classes in Biology on English on example of senior high school. 


\section{Methods}

The main research was carried out on the basis of Karaganda regional specialized boarding school «Daryn» in 2019-2020.

The experiment was conducted with two mixed groups from the 9th grades, the total number of respondents - 20 people. 10 school-students are the control group, and 10 school-students are the experimental group. The control group received texts on Zoology of 500-600 words for translation without a dictionary, experimental - using a trilingual dictionary on Zoology [11, 12]. For translation from English to Russian we used tree texts: 1) Cells and Protoplasts; 2) Protozoa. Amoeba; 3) Crayfish. For translation from Russian to English we also used tree texts: 1) Earthworm; 2) Frog; 3) Structure of insects. Ehe texts describe the cell and its main parts, the structure, distribution and features of animal habitation.

Texts were given in English for translation into Russian as well as in Russian for translation into English. In each variant, school-students were given a time limit of 20 minutes to translate one text. In assessing the results, we took into account the following indicators:

-The accuracy of the translation (high, medium, low) by assessing the general meaning and correctness of the use of terms (Tab. 1);

-The school-students met the deadline during translation -20 minutes (yes, no).

T a b l e 1

\section{Criteria for assessment of the accuracy of the translation}

\begin{tabular}{|l|l|l|l|}
\hline \multicolumn{1}{|c|}{ Criteria } & \multicolumn{1}{|c|}{ High level } & \multicolumn{1}{c|}{ Average level } & \multicolumn{1}{c|}{ Low level } \\
\hline $\begin{array}{l}\text { Meaningful identity of the } \\
\text { translation text }\end{array}$ & $\begin{array}{l}\text { Equivalent translation: } \\
\text { meaningful identity of the } \\
\text { translation text }\end{array}$ & $\begin{array}{l}\text { Translation errors: transla- } \\
\text { tion errors do not violate } \\
\text { the general meaning of the } \\
\text { original }\end{array}$ & $\begin{array}{l}\text { Non-equivalent transfer of } \\
\text { meaning: errors represent a } \\
\text { distortion of the content of the } \\
\text { original }\end{array}$ \\
\hline $\begin{array}{l}\text { Grammatical aspects of the } \\
\text { translation }\end{array}$ & $\begin{array}{l}\text { Use of grammatical equiva- } \\
\text { lents for 30\% of text }\end{array}$ & $\begin{array}{l}\text { Use of grammatical equiv- } \\
\text { alents for 60-70\% of text }\end{array}$ & $\begin{array}{l}\text { Equivalent translation using the } \\
\text { basic grammatical construc- } \\
\text { tions characteristic of the sci- } \\
\text { entific text }\end{array}$ \\
\hline $\begin{array}{l}\text { Observance of language } \\
\text { norms and rules of transla- } \\
\text { tion language: stylistic iden- } \\
\text { tity of translation text }\end{array}$ & $\begin{array}{l}\text { Compliance with language } \\
\text { and translation language } \\
\text { rules for 30\% of the text }\end{array}$ & $\begin{array}{l}\text { Compliance with language } \\
\text { and translation language } \\
\text { rules for 60-70\% of the } \\
\text { text }\end{array}$ & $\begin{array}{l}\text { Observance of language norms } \\
\text { and rules of translation lan- } \\
\text { guage of scientific text }\end{array}$ \\
\hline
\end{tabular}

After two tasks each school-student of control group noted the frequency of using the dictionary:

- Examined in dictionary 1-2 terms;

- Examined 3-5 terms in the dictionary;

- Examined more than 5 terms in the dictionary.

\section{Results and discussion}

The analysis of results showed that translation accuracy between control and experimental group differs. So, school-students without using of the dictionary were estimated at average and low level at the translation of texts from English into Russian (Table 2, Fig. 1) and as low level at the translation from Russian into English (Table 3, Fig. 2). The experimental groups with using the dictionary the translation quality was estimated higher than for control group without dictionary.

Table 2

Assessment of the level of translation of texts on Zoology from English to Russian

\begin{tabular}{|l|c|c|c|}
\hline \multirow{2}{*}{ Group } & \multicolumn{3}{c|}{ Amount of school-students } \\
\cline { 2 - 4 } & High level & Average level & Low level \\
\hline Control, without dictionary (10 people) & 2 & 4 & 4 \\
\hline Experimental, with dictionary (10 people) & 4 & 5 & 1 \\
\hline
\end{tabular}




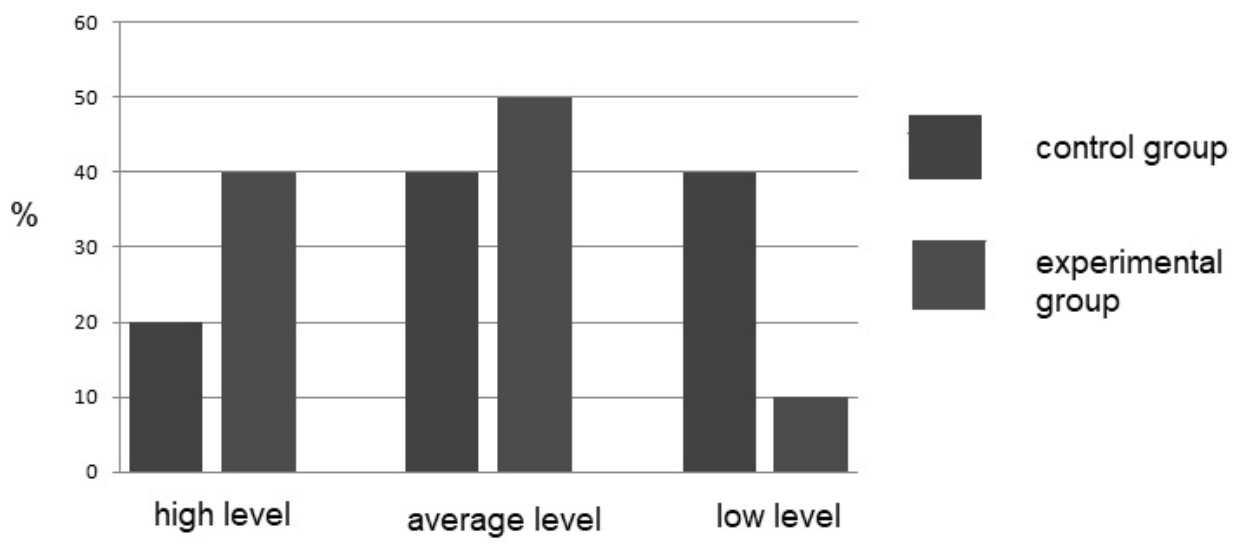

Figure 1. Percent of school-students with different level of translation from English to Russian

Ta b l e 3

Assessment of the level of translation of texts on Zoology from Russian to English

\begin{tabular}{|l|c|c|c|}
\hline \multirow{2}{*}{ Group } & \multicolumn{3}{c|}{ Amount of school-students } \\
\cline { 2 - 4 } & High level & Average level & Low level \\
\hline Control, without dictionary (10 people) & 0 & 3 & 7 \\
\hline Experimental, with dictionary (10 people) & 2 & 7 & 1 \\
\hline
\end{tabular}

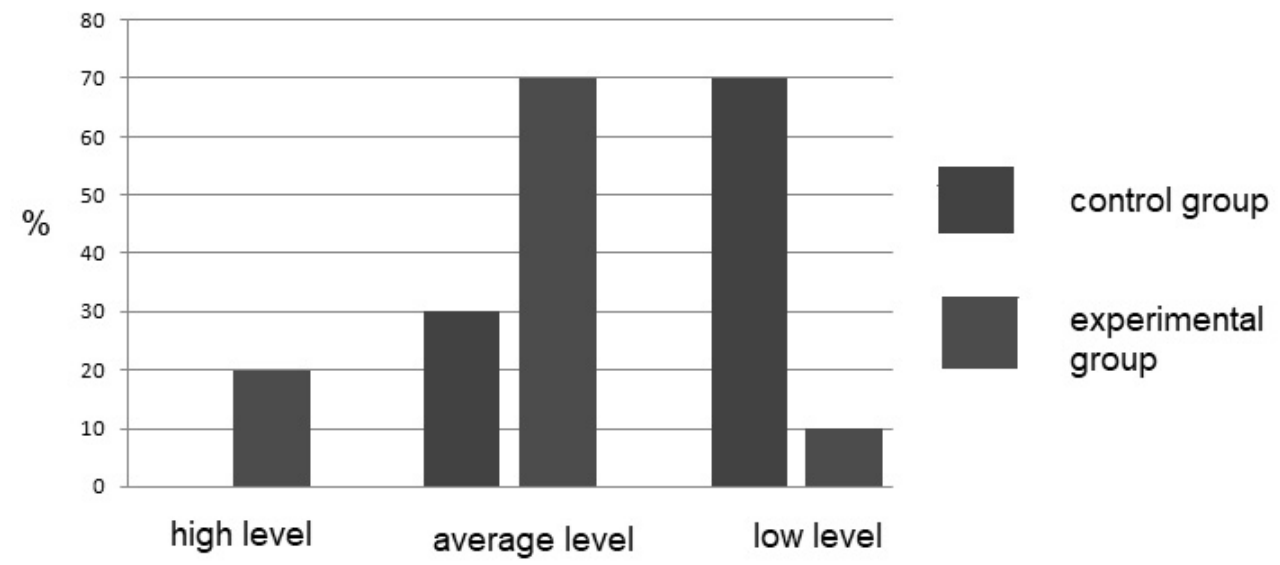

Figure 2. Percent of school-students with different level of translation from Russian to English

That is we observed a reliable difference between control and experimental group. So, at the translations from English into Russian the control group was distributed as follows: $20 \%$ with high level, $40 \%$ with average and $40 \%$ with low level. At the translation from Russian into English made distribution: high level $-0 \%$, average $-30 \%$, low $-70 \%$.

In experimental group at the translation from English for the Russian $40 \%$ of pupils showed high level, $50 \%$ - average and only $10 \%$ - low. It was on $20 ; 10$ and $30 \%$ higher than similar indicators of control group. At the translation from Russian into English the share with high level made $20 \%$, with average level $70 \%$ and with low level $10 \%$. These data exceeded similar results of control group on $20 ; 40$ and $60 \%$, respectively.

All school-students noted, as was confirmed with results of an experiment that it is easier to do the translation from English into Russian, than to translate from Russian into English.

It should be noted that not all school-students, who participated in an experiment with using dictionary and without, completed the tasks in 20 minutes. In control group the share of school-students, who did not make the translation in 20 minutes was higher, than in experimental group (Table 4). 
Evaluation of translation time indicators

\begin{tabular}{|l|c|c|c|c|}
\hline \multirow{2}{*}{ Group } & \multicolumn{2}{|c|}{ Translation from English to Russian } & \multicolumn{2}{c|}{ Translation from Russian to English } \\
\cline { 2 - 5 } & $\begin{array}{c}\text { Completed the task } \\
\text { in 20 minutes, people }\end{array}$ & $\begin{array}{c}\text { Took more time, } \\
\text { people }\end{array}$ & $\begin{array}{c}\text { Completed the task } \\
\text { in 20 minutes, people }\end{array}$ & $\begin{array}{c}\text { Took more time, } \\
\text { people }\end{array}$ \\
\hline $\begin{array}{l}\text { Control, without dictionary } \\
\text { (10 people) }\end{array}$ & 8 & 2 & 3 & 7 \\
\hline $\begin{array}{l}\text { Experimental, with dic- } \\
\text { tionary (10 people) }\end{array}$ & 9 & 1 & 7 & 3 \\
\hline
\end{tabular}

Analysis of the obtained data shows that 8 school-students in the control group completed task in time during translating from English to Russian, and two pupils took longer. In the experimental group 9 schoolstudents completed in time, and only one school-student took more than 20 minutes for translation.

In variant with translating from Russian to English in the control group completed the tasks in 20 minutes 3 school-students, and 7 people spent more time. In the experimental group 7 school-students completed tasks in time; and 3 school-students spent more than 20 minutes. That is, the difference in the first variant of translation was 1 person; in the second variant were 4 persons.

In conclusion, we analyzed the frequency of using the dictionary for the experimental group (Table 5).

Table 5

Frequency of using terms when translating texts on Zoology

\begin{tabular}{|l|c|c|c|}
\hline \multicolumn{1}{|c|}{ Variant of translation } & $1-2$ terms & $3-5$ terms & More than 5 terms \\
\hline $\begin{array}{l}\text { Translation from English } \\
\text { to Russian }\end{array}$ & 2 & 6 & 2 \\
\hline $\begin{array}{l}\text { Translation from Russian } \\
\text { to English }\end{array}$ & 1 & 3 & 6 \\
\hline
\end{tabular}

The obtained data showed that for the translation from English into Russian the school-students used the trilingual dictionary in the lesser extent, than at the translation from Russian into English.

So, in the first variant of translation 2 school-students noted that they used no more than 2 terms, 6 people - watched the translation of 3-5 terms, and 2 school-students noted that they used more than 5 terms.

At the second variant of translation only 1 school-student noted that he used the dictionary for search of 1-2 terms, 3 school-students marked that used from 3 to 5 terms, and the 6 school-students - more than 5 terms.

Thus, results of researches show that application of the trilingual dictionary at lessons of Biology might help with understanding of specialized texts and the translation of scientific texts.

\section{Conclusion}

The introduction of the program of trilingual education at all levels of the education in the Republic of Kazakhstan implies the development of the system of education of subjects of the natural scientific cycle, including Biology in English. One of the problems of educational institutions is the lack of a proper level of knowledge of English, especially specialized terminology.

Based on the above, there is a need to conduct research on the organization of Biology education in English using various teaching tools, including trilingual terminology dictionaries and glossaries.

The effectiveness of the trilingual dictionary on Zoology in additional biology classes in English was evaluated. The results of the studies show that the application of the trilingual dictionary in Biology lessons reliably increases the level of understanding of specialized texts and translation of scientific materials. Use of the dictionary on zoology increases the efficiency of translation from English to Russian on $20 \%$ with high level, $40 \%$ with average level and $40 \%$ with low level. At the translation from Russian into English the efficiency of translation was the following: high level $-0 \%$, average level $-30 \%$, low level $-70 \%$.

During translation from English to Russian, the number of school-students, who completed into 20 minutes, was more on $10 \%$ in the experimental group. In process of translation from Russian to English, the number of school-students, who completed the task at 20 minutes, was also more on $40 \%$ in the experi- 
mental group. All school-students of experimental group noted the difficulty of translating from Russian to English.

The research was carried out within the framework of the grant project of the Ministry of Education and Science of Kazakhstan "Creation of a trilingual dictionary of biological terms with a linguoculturological component».

\title{
References
}

1 Государственная программа развития образования в Республике Казахстан на 2011-2020 годы. Указ Президента Республики Казахстан № 110 от 29.01.2011 г. - Астана, 2011. [Электронный ресурс]. — Режим доступа http://adilet.zan.kz/rus/docs/U1000001118.

2 Жетписбаева Б.А. От идеи «триединство языков» Н.А. Назарбаева до полиязычного образования в Казахстане / Б.А. Жетписбаева, О.Т. Аринова // Вестн. Караганд. ун-та. Сер. Филол. — 2012. — № 3. — С. $12-16$.

3 Об особенностях преподавания основ наук в общеобразовательных организациях (в том числе реализующих инклюзивное образование) Республики Казахстан в 2014-2015 учебном году: инструкт.-метод. письмо. — Астана: Национальная академия образования им. И. Алтынсарина, 2014. - 181 с.

4 Ишмуратова М.Ю. Оценка подготовленности учащихся среднего звена школы к обучению биологии на английском языке / М.Ю. Ишмуратова // Молодежь и глобальные проблемы современности: материалы Респ. науч.-практ. конф. студентов, магистрантов, докторантов и молодых ученых. - Т. 3. - Караганда, 2016. - С. 21-25.

5 Kalizhanova A. Creation of an electronic trilingual dictionary of biological terms with linguocultural components / A. Kalizhanova, T. Maryshkina, M. Ishmuratova, Ye. Gruzina, B. Ibrayeva // Opcion. — 2020. — Vol. 36, No. 27. — P. $705-723$.

6 Ishmuratova M.Yu. Analysis of the terms of the school course of biology and formation of the concept of presentation of information for the creation of a trilingual dictionary / M.Yu. Ishmuratova, A.N. Kalizhanova, T.V. Maryshkina, G. Dyke, S.U. Tleukenova // Bulletin of the Karaganda University. Series Biology. Medicine. Geography. — 2019. — No. 4(96). — P. 20-26.

7 Пассов П.В. Принципы иноязычного образования, их система и иерархия / П.В. Пассов // Материалы ХІІІ Конгр. Междунар. орг. преп. рус. яз. и лит. - Гранада, 2015. - 143 с.

8 Байниева К.Т. Функциональная значимость трехъязычных словарей в полиязычном образовании / К.Т. Байниева, А.Ж. Умурзакова // Междунар. журн. приклад. и фундамент. иссл. - 2015. - № 8-4. - С. 776-779.

9 Жакупова А.Д. Информативные возможности многоязычного мотивационно-сопоставительного словаря как словаря нового типа / А.Д. Жакупова // Вестн. Томск. гос. ун-та. Сер. филол. — 2011. — № 3(15). — С. 38-44.

10 Олжанова А.Д. Создание трехъязычных словарей биологических терминов / А.Д. Олжанова, М.Ю. Ишмуратова, А.Н. Калижанова, Б.М. Ибраева // Методология, теория и практика современной биологии: материалы V Междунар. науч.практ. конф. - Костанай, 2020. - С. 600-604.

11 Ишмуратова М.Ю. Англо-русско-казахский, русско-англо-казахский, казахско-англо-русский словарь по зоологии (для общеобразовательных школ) / М.Ю. Ишмуратова, А.Н. Калижанова, Т.В. Марышкина, Г.Ш. Оразгалиева. - Караганда: РИО «Болашак-Баспа», 2018. - 68 с.

12 Золотова М.В. Ботаника и зоология: сб. текстов и заданий по английскому языку: практ. / М.В. Золотова. - Нижний Новгород: Изд-во Нижне-Новгород. гос. ун-та, 2017. — 68 с.

\section{М.Ю. Ишмуратова, А.Н. Калижанова, А.Ә. Ережеп, Т.Ю. Шелестова}

\section{Ағылшын тілінде биологияны оқытуда арнайы сөздік қолданудың тиімділігі}

\begin{abstract}
Қазақстанда білім берудің жаңартылған мазмұнына көшу барысында биология бойынша сабақтарды ағылшын тіліндегі қажетті материалдармен қамтамасыз ету мәселесі тұр. Мектеп және жоғары білім беру деңгейінде биология бойынша оқулықтар, құралдар мен үш тілді сөздіктердің жетіспеушілігі анықталған. Бұл аспект биология бойынша білімді ағылшын тілінде меңгеруге, терминдердің аудармасын табысты түсінуге, аудармалар жасауға мүмкіндік бермейді. Мақалада мектептің орта буынында үш тілді сөздікті (ағылшын-орысша-қазақша, орысша-қазақша-ағылшынша және қазақшаағылшынша-орысша) қолданудың тиімділігін зерттеу бойынша материалдар баяндалған. Биология пәнінен ағылшын тілінде қосымша сабақ өткізу кезінде зоология бойынша үш тілді сөздікті қолдану тиімділігі бағаланды. Зерттеу нәтижелері биология сабақтарында үш тілді сөздікті қолдану мамандандырылған мәтіндерді түсіну және ғылыми материалдарды аудару деңгейін дұрыс арттыратынын көрсетті. Зоология сөздігін пайдалану ағылшын тілінен аударудың тиімділігін арттырады.
\end{abstract}

Кілт сөздер: үш тілді сөздік, мектеп, аударма бойынша эксперимент, биологияны ағылшын тілінде оқыту, мамандандырылған биологиялық терминдер, аударма дәлдігі. 


\title{
М.Ю. Ишмуратова, А.Н. Калижанова, А.А. Ережеп, Т.Ю. Шелестова \\ Эффективность применения специализированного словаря при обучении биологии на английском языке
}

\begin{abstract}
В Казахстане в процессе перехода образования на обновленное содержание стоит проблема обеспечения занятий по биологии необходимыми материалами на английском языке. На школьном и вузовском уровнях выявлен недостаток учебников, пособий и трехъязычных словарей по биологии. Данный аспект не позволяет успешно усваивать знания по биологии на английском языке, понимать перевод терминов, осуществлять точные переводы. В статье изложены материалы по изучению эффективности применения трехъязычного словаря (англо-русско-казахский, русско-казахско-английский и казахскоангло-русский) в среднем звене школы. Оценена эффективность применения трехъязычного словаря по зоологии при проведении дополнительных занятий по биологии на английском языке. Результаты исследований показывают, что применение трехъязычного словаря на уроках биологии достоверно повышает уровень понимания специализированных текстов и перевода научных материалов. Использование словаря по зоологии повышает эффективность перевода с английского на русский язык и с русского на английский, сокращает время, затрачиваемое на перевод.
\end{abstract}

Ключевые слова: трехъязычный словарь, школа, эксперимент по переводу, обучение биологии на английском языке, специализированные биологические термины, точность перевода.

\section{References}

1 Hosudarstvennaia prohramma razvitiia i funktsionirovaniia yazykov v Respublike Kazakhstan na 2011-2020 hh. Ukaz Prezidenta RK № 110 ot 29.04.2011 [State program of development and function of languages in Republic of Kazakhstan on 20112020. The law of President of RK № 110 from 29.04.2011]. (2011). Astana [in Russian]. - URL: http://adilet.zan.kz/rus/docs/U1000001118.

2 Zhetpisbayeva, B.A., \& Arinova, O.T. (2012). Ot idei «triedinstvo yazykov» N.A. Nazarbaeva do poliiazychnoho obrazovaniia v Kazakhstane [From idea «Tri unity of languages» of N.A. Nazarbayev until multilingual education in Kazakhstan]. Vestnik Karahandinskoho universiteta. Seriia Filolohiia - Bulletin of Karaganda University. Series Philology, 3(88), 12-16 [in Russian].

3 Ob osobennostiakh prepodavaniia osnov nauk $v$ obshcheobrazovatelnykh orhanizatsiiakh (v tom chisle realizuiushchikh inkliuzivnoe obrazovanie) Respubliki Kazakhstan v 2014-2015 uchebnom hodu: instruktivno-metodicheskoe pismo [About the features of teaching the basics of science in General education organizations (including those implementing inclusive education) of the Republic of Kazakhstan in the 2014-2015 academic year. Instructional and methodological letter]. (2014). Astana: I. Altynsarin National Academy of Education [in Russian].

4 Ishmuratova, M.Yu. (2016). Otsenka podhotovlennosti uchashchikhsia sredneho zvena shkoly k obucheniiu biolohii na anhliiskom yazyke [Assessment of the readiness of secondary school students to learn biology in English]. Proceeding from: Youth and global problems of modernity: Respublikanskaia konferentsiia - Republican Conference. Karaganda, 3, 21-25 [in Russian].

5 Kalizhanova, A., Maryshkina T., Ishmuratova, M., Gruzina, Ye., \& Ibrayeva, B. (2020). Creation of an electronic trilingual dictionary of biological terms with linguocultural components. Opcion, 36, 27, 705-723.

6 Ishmuratova, M.Yu., Kalizhanova, A.N., Maryshkina, T.V., Dyke, G., \& Tleukenova S.U. (2019). Analysis of the terms of the school course of biology and formation of the concept of presentation of information for the creation of a trilingual dictionary. Bulletin of the Karaganda University. Series Biology. Medicine. Geography, 4(96), 20-26.

7 Passov, P.V. (2015). Printsipy inoiazychnoho obrazovaniia, ikh sistema i ierarkhiia [Principles of foreign language education, their system and hierarchy]. Proceedings from: XIII Congress of International Organization of Teachers of Russian Language and Literature: Respublikanskaia konferentsiia - Republican Conference. Granada, 143 [in Russian].

8 Bainiyeva, K.T., \& Umyrzakova, A.Zh. (2015). Funktsionalnaia znachimost trekh yazychnykh slovarei v poliiazychnom obrazovanii [Functional significance of trilingual dictionaries in multilingual education]. Mezhdunarodnyi zhurnal prikladnykh $i$ fundamentalnykh issledovanii - International journal of applied and fundamental research, 8-4, 776-779 [in Russian].

9 Zhakupova, A.D. (2011). Informativnye vozmozhnosti mnohoyazychnoho motivatsionno-sopostavitelnoho slovaria kak slovaria novoho tipa [Informative features of a multilingual motivational-comparative dictionary as a new type of dictionary]. Vestnik Tomskoho hosudarstvennoho universiteta. Seriia filolohiia - Bulletin of Tomsk State University. Series philology, 3(15), 38-44 [in Russian].

10 Olzhanova, A.D., Ishmuratova, M.Yu., Kalizhanova, A.N., \& Ibrayeva, B.M. (2020). Sozdanie trekhiazychnykh slovarei biolohicheskikh terminov [Creation of trilingual dictionary of biological terms]. Proceeding from: Methodology, theory and practice of modern biology: V Mezhdunarodnaia konferentsiia - V International Conference. Kostanai, 600-604 [in Russian].

11 Ishmuratova, M.Yu., Kalizhanova, A.N., Maryshkina, T.V., \& Orazgaliyeva, G.Sh. (2018). Anhlo-russko-kazakhskii, russkoanhlo-kazakhskii, kazakhsko-anhlo-russkii slovar po zoolohii (dlia obshcheobrazovatelnykh shkol) [English-Russian-Kazakh, Russian-English-Kazakh, Kazakh-English-Russian dictionary on zoology (for secondary school)]. Karaganda: Bolashaq-Baspa [in Russian, in Kazakh, in English].

12 Zolotova, M.V. (2017). Botanika i zoolohiia: sbornik tekstov i zadanii po anhliiskomu yazyku: praktikum [Botany and zoology: collection of texts and tasks in English: workshop]. Nizhny Novgorod: Publ. of Nizhny Novgorod State University [in Russian, in English]. 